\title{
Monetary Inflation Mechanism. An Empirical View
}

\author{
PhD Assoc. Prof, Liviu C. Andrei \\ National University of Political and Administration Sciences \\ Bucharest, Faculty of Public Administration \\ E-mail: liviucandrei@yahoo.com
}

\section{PhD Senior Researcher Dalina Andrei}

Economic Forecasting Institute, Romanian Academy

E-mail: dalinaandrei@yahoo.com

\begin{abstract}
We prefer to reconsider once again our larger paper published earlier ${ }^{1}$, as we did it already for at least three of its revealed correlations: between nominal GDP and both monetary reserves and money supply (Andrei \& Andrei 2014a, b) and between money multiplier and velocity (Andrei 2014), this time for something within our database (i.e. the Federal Reserves of Saint Lois State/FRED) that regards the inflation rate from nearby. Following our basic paper reference's basics, inflation might be proper to both representative and fiat monies, but more deeply to the latter, although both monies again keep either the money supply and reserves as components. On the other hand, the same inflation is a so reach topic for theorists of all groups of thinking, e.g. there are some that identify it out of just money origins. This paper below tries to explain a monetary inflation mechanism in normal (out of crisis) environment.
\end{abstract}

Keyconcepts: inflation (rate), (required \& excess) monetary reserves, Fed, cointegration, fiat money, money supply

JEL Classification: B1, C5, E5

1 Andrei, LC \& Andrei, D (2014). 


\section{Introduction}

As much as in our referred paper (Andrei \& Andrei 2014) we will here try to deepen the relationship between inflation and excess (monetary) reserves, namely what FRED ${ }^{2}$ calls Excess Reserves of Depository Institutions: those deposits held by depository institutions at the Fed not used to satisfy statutory reserve requirements plus that vault cash held by the same institutions not used to satisfy statutory reserve requirements. Excess reserves (EXCRESNS, as noted by FRED or $\mathrm{Rx}$ by us, as primarily) equals total reserves less required reserves ${ }^{3}$.

As for total reserves (Mo), they belong to all commercial banks and appropriate institutions and are managed by Fed. Just mentioning also that actually Mo includes $\mathrm{M} 1$, as opposite to the next following monetary aggregates (M1, M2, M3) integration rule (M1, M2, M3). Moreover, M1 accounts twice within the Fed's monetary base - first as included in Mo, next as individually in the monetary aggregates' successive integration ${ }^{4}$.

The excess reserves ( $\mathrm{Rx} / \mathrm{EXCRESNS})$ might here reflect the banks' abstention from crediting on the investments level, given an inflation rate already reached. In reality, the inflation rate level isn't supposed to be fully endogenized by happenings of the banking system only ${ }^{5}$. This description will be continuing by the below comment.

\section{The model, as shortly}

Then, the excess reserves $\left(\mathrm{Rx}_{\mathrm{x}} / \mathrm{R} \mathrm{t}\right)$ and inflation $(\mathrm{IR})$ rates basic equation reports as follows:

$\mathrm{Rx} / \mathrm{Rt}=(\mathrm{A})+(\mathrm{B}) \mathrm{IR}$

2 As by initials (FRED): Federal Reserves Economic Data/ actually Federal Resereves of Saint Lois State.

3 EXCRESNS or Rx are denominated in bill.\$ and accounted as monthly, not seasonally adjusted and discontinued series.

4 That results from the central bank's balance sheet's accounting M1 on both assets (left hand side) and liabilities (right hand side / Andrei \& Andrei 2014, p 15).

5 Otherwise, the US' GDP evolving since 1959 seems to be rather continuous and no growth irregularities on both mirrors that are its nominal and real levels. 
where (A) and (B) are constant. And all these above for yearly data series within the 1961-2007 interval, namely 47 pair observations, after adjustments (Andrei $\&$ Andrei 2014, pp. 88-94; 147-151). See the two series in the next graph:

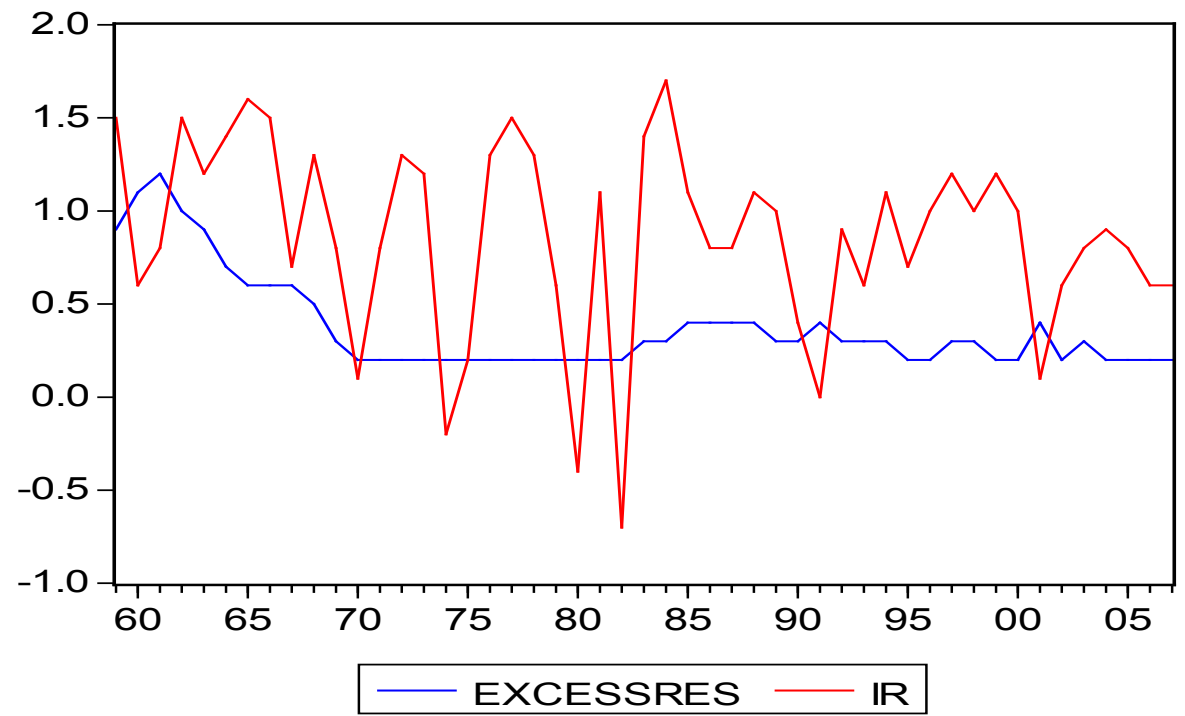

And they actually prove stationary - actually, we all know this is rather rare. However, the above basic equation was then leaved behind for its weak outcomes and then, the chosen Trace test indicates two co-integrating equations at the 0.05 null probability level and two time lags $(-1 ;-2)$ that will replace it, as follows:

\begin{tabular}{|c|c|c|c|c|}
\hline \multicolumn{5}{|c|}{ Date: 02/19/14 Time: $13: 50$} \\
\hline \multicolumn{5}{|c|}{ Sample (adjusted): 19612007} \\
\hline \multicolumn{5}{|c|}{ Included observations: 47 after adjustments } \\
\hline \multicolumn{5}{|c|}{ Trend assumption: Linear deterministic trend } \\
\hline \multicolumn{5}{|c|}{ Series: EXCESSRES IR } \\
\hline \multicolumn{5}{|c|}{ Lags interval (in first differences): 1 to 1} \\
\hline \multicolumn{5}{|c|}{ Unrestricted Cointegration Rank Test (Trace) } \\
\hline \multicolumn{2}{|l|}{ Hypothesized } & Trace & 0.05 & \\
\hline No. of $C E(s)$ & Eigenvalue & Statistic & Critical Value & Prob.** \\
\hline None * & 0.4215 & 35.665690 & 15.494710 & 0.0000 \\
\hline At most $1^{*}$ & 0.190653 & 9.941798 & 3.841466 & 0.0016 \\
\hline
\end{tabular}


The same as Vector Errors Correction (VEC) type test and model.

\begin{tabular}{|l|r|l|r|r|}
\hline \multicolumn{2}{|l|}{ Hypothesized } & Max-Eigen & $\mathbf{0 . 0 5}$ & \\
\hline No+ of CE $(\mathbf{s})$ & Eigenvalue & Statistic & Critical Value & Prob* $^{* *}$ \\
\hline None & 0.4215 & 25.72389 & 14.2646 & 0.0005 \\
\hline At most $1^{*}$ & 0.190653 & 9.941798 & 3.841466 & 0.0016 \\
\hline
\end{tabular}

Equation 1: D(EXCESSRES $)=-0.156198$ [EXCESSRES $(-1)-1.973203581^{*}$ $\operatorname{IR}(-1)+0.16888253]-0.034248 \mathrm{D}(\operatorname{EXCESSRES}(-1))+0.071017$ $\mathrm{D}($ EXCESSRES $(-2)-0.054865 \mathrm{D}(\operatorname{IR}(-1))-0.013633 \mathrm{D}(\operatorname{IR}(-2))-0.021536$

\begin{tabular}{|l|l|l|r|}
\hline Observations: 46 & & \\
\hline R-squared & 0.206703 & Mean dependent var & -0.02174 \\
\hline Adjusted R-squared & 0.107541 & S.D. dependent var & 0.084098 \\
\hline S.E. of regression & 0.079447 & Sum squared resid & 0.252475 \\
\hline Durbin-Watson stat & 1.960051 & & \\
\hline
\end{tabular}

Equation 2: D $(\mathrm{IR})=1.527922\left[\operatorname{EXCESSRES}(-1)-0.5987051985^{*} \mathrm{IR}(-1)+\right.$ $0.16888253]+0.692735 \mathrm{D}$ (EXCESSRES $(-1))-0.235387 \mathrm{D}$ (EXCESSRES( $-2))+0.10665 \mathrm{D}(\operatorname{IR}(-1))+0.083318 \mathrm{D}(\mathrm{IR}(-2))+0.006892$

\begin{tabular}{|l|l|l|l|}
\hline Observations: 46 & & \\
\hline R-squared & 0.456399 & Mean dependent var & -0.00435 \\
\hline Adjusted R-squared & 0.388448 & S.D. dependent var & 0.696645 \\
\hline S.E. of regression & 0.544789 & Sum squared resid & 11.87178 \\
\hline Durbin-Watson stat & 2.100097 & & \\
\hline
\end{tabular}

In which, EXCESSRES replaces the above $\mathrm{Rx}_{\mathrm{x}} / \mathrm{R}$ t ratio, and D(EXCESSRES) and $\mathrm{D}$ (IR) are differentials of the excess reserves and inflation rates, as respectively. The long term causality connection is so revealed as the very strength of this model. In Equation 1 - of the excess reserves differential endogenous -- the first coefficient (0.156198 ) appears negative and much lower than $5 \%$ null probability. This is similar for -0.054865 (of precedent period inflation rate differential) and -0.013633 (of the ante-precedent period inflation rate) and - 0.021536(the free coefficient) when the 
same current excess reserves endogenous, these coefficients revealing short term connections between variables.

On the contrary, for Equation 2 - of the inflation rate differential endogenous - only the first coefficient (1.527922) proves significant for all: its low null probability, absolute value and positive sign (direct relationship between variables disputed). Plus, for the long term causality it becomes similarly interesting that the inflation rate differential endogenous seems to be once more in advantage against excess reserves differential endogenous, and this for both R-squared and Durbin-Watson statistics.

Granger causality, in its turn, here also proves one-way: only excess reserves succeed a $10 \%$ part of inflation rate up to 15 time lags, and no any reciprocal influence. There is an equally normal errors' distribution and these errors prove bomoscedastic.

Shortly, the most highly significant influence in the above model seems to be one of the excess reserves on inflation ${ }^{6}$.

\section{Comments}

The first challenge of this above result is for the so vast description of inflation as a multiple exogenous function in the whole literature ${ }^{7}$ - here we see the strong monetary influence on it as refound.

Then, look at this monetary acting on inflation: this is through excess reserves, that apparently means just the opposite of the active crediting - interesting, isn't it? Actually, it might be so, but here do not omit that this model reveals such fact on longer time - so, when more monetary cycles accounted this might really be active crediting turning into excess reserves exactly for basically being inflationary nature. Another interesting point might be a similarity between inflation and, let us here recall the external balances, e.g. trade balance, current account and even total balance of payments, the really influential factor here being the trade balance. What I mean is that the trade balance accounts on the short (cyclical)

6 Whereas the inflation's influence on excess reserves also proves certain, but negative and weak enough (Andrei \& Andei 2014, p. 151). Besides, the authors develop the same model on quarterly data series for the period between qt. II 1959 and qt. I 2007, so for 190-192 pair obserevations, after adjustments, with less significant results.

7 I.e. from demand-pull and cost-push inflation (classics and neoclassics) to differences between aggregate demand and supply and unemployment's contribution (Keynes, Keynesians and post-Keynesians etc.). 
term, but its determinants work for shaping similar phisionomy to a longer series of successive trade balances (e.g. commercial contracts between residential and non-residential partners). So works the inflation, here especially the monetary part of it - e.g. through all output, supplies, cost, demand or unemployment factors. Thirdly, money seems to work on inflation through (monetary) reserves (Mo), as directly. Or, this is, even more, to talk about since dealing with two types of money and here assuming the above model working on the fiat post-war US dollar, as exclusively ${ }^{8}$. And even not only.

One more question is that whether and how exactly deal the monetary reserves with inflation - do they do it for both fiat and representative monies, as similarly or specifically? Or, actually, such a question requires a whole set of relative questions answered on the same reserves, i.e. how reserves do work in both representative and fiat monies cases?

Then, look at the important similarities: both monetary systems need reserves and this for directly acting on inflation - at, the other end' representative money (reserves) look(s) non-inflationary, whereas fiat money (reserves) look(s) inflationary as by definition. So, explanations needed for both.

As for representative money, things are simpler, namely reserves are exogenous (for money supply) within the monetary system. Is this enough for the presumable non-inflationary picture? Of course, not - here, money is, represented' by an individual (be it) non-monetary reference of different price evolving against all (the other) market goods.

All that can be asserted is that representative money appears this way as a simpler picture than the other (fiat money) opposed system that will be immediately described below. But the retort here might be that the example of gold standard appears non-inflationary (Andrei, 2011, p.186) to all those arguing about it ${ }^{9}$. So, which is the immediate truth? The truth here is that this gold reference results from a tremendously long artificial selection and market competition between monetary references (Andrei, 2011, p. 143) - and this might be the other similarity between representative and fiat money systems, namely the long term

8 Just skipping the Andrei \& Andrei (2014)'s argument advanced on the existent mixture of representative and fiat money.

9 And that whilst a large plurality of opinions on the so controversial topic that gold standard is (Andrei, 2011, pp. 220-226). 
acting on their (own \& specific) monetary reserves. As for the opposite fiat money, essentially, the exogenous shifts from reserves to money supply, whereas, though, reserves still exist in such conditions, work on the same money supply and keep a good word on inflation as well. All that here keeps more complicated than in the other representative money system and case is a kind of Hegelian-Marxian ,dialectique', through which, first, money supply (instead of an external reference value, as in the other system-case) makes itself the reserves, then the last do adjust the same money supply - but this is the next cyclical timing of the latter.

\section{As concluding}

Of which process, the excess reserves might be the extra result and/or both inflation producer and, possibly, then the self-adjusting tool of total reserves in such non-representative money specific environment.

\section{References}

1. Andrei, LC \& Andrei D (2014): Fiat, versus representative money under debate (II). A case study of thw US'Federal Reserve's monetary base along the postwar. LAP Lambert Academic Publishing. 198 pages.

2. ISBN 978-3-659-57947-9. Saarbrücken. Germany. 8 August, 2014.

3. Andrei, LC \& Andrei D (2014a): Contemporary money issues. A study developing on the US Federal Reserves monetary base. In proceeding of: MBFEU 2014, At A. I. Cuza University of Iasi, Romania, Volume: "Monetary, Banking and Financial Issues in Central and Eastern EU member countries". June 2014.

4. Andrei, LC \& Andrei D (2014b): Another Monetary Inflation Coordinate. Excess reserves and inflation rate Studies On The US Federal Reserves' Monetary Base. Paper presented at the Conference hold by the Ecological University of Bucharest

5. Andrei, LC (2014): Money Multiplier and Velocity Playing for Money Neutrality. Working Paper. MonetaryEconomicse-Journal. Vol. 6, No. 173: Oct 23, 2014; Macroeconomics:Monetary and Fiscal Policiese-JOURNAL, Vol. 7, No. 142: Oct 22, 2014

6. Andrei, LC (2011): Money and Market in the Economy of all Times. Xlibris. co Daartford \& Bloomington 2011

7. FRED / Federal Reserves Economic Data / Federal Reserves of St. Louis / data on monetary base / http://research.stlouisfed.org/ 